History: Power, Agency and Experience from the Sixteenth to the Twentieth Century (London, 1996), 39-56, quotation at 43. See also Rowlands, 'Witchcraft and old women', 69-78; Bever, 'Witchcraft, female aggression, and popular belief', 956-7.

82. R. B. Shoemaker, Gender in English Society, 1650-1850: The Emergence of Separate Spheres? (London, 1998), ch. 3; Foyster, Manhood in Early Modern England, chs 2-4; Amussen, "The Part of a Christian Man"', 214.

83. Amussen, "The Part of a Christian Man"', 227.

84. Crooke, Microcosmographia, 276.

85. Briggs, Witches and Neighbours, 286.

86. Apps and Gow, Male Witches, 38. Discussing witchcraft, Heide Wunder has urged the active historicization of gender relations, so as to resist 'the ceaseless mythologizing that seeks to pin women down': He is the Sun, She is the Moon: Women in Early Modern Germany (Cambridge MA, 1998), ch. 8, quotation at $151-2$.

87. Kent, 'Masculinity and male witches', 86.
9

\section{The Werewolf, the Witch, and the Warlock: Aspects of Gender in the Early Modern Period}

Willem de Blécourt

It has been suggested that the figure of the malevolent witch developed historically not merely in opposition to, but 'in part, from' that of the male sorcerer, or the practitioner of ritual magic. ${ }^{1}$ This idea should be questioned, however, or at least qualified. In the context of the early witch-trials, witches were obviously closely related to heretics; in terms of imagery, they seem to have possessed traits in common with fairies. ${ }^{2}$ In the context of medieval Europe, sorcerers have to be situated vis-à-vis clergymen, physicians, prophets, and mystics, although these were all categories of masculine power and expertise that frequently overlapped, even during this period. Moreover, the figure of the sorcerer himself was complex and in need of differentiation: it might denote a court astrologer, a necromancer, an occult philosopher, a fortune-teller, a local cunning man, or merely an occasional dabbler in the hidden arts, to name just a few possibilities. Did the figure of the sorcerer slip 'in and out of various categories in disconcerting fashion, making it difficult to pin down exactly what makes him different from any other kind of magical practitioner'? ${ }^{3}$ Was a magician, to use another term, always necessarily male? The oppositions inherent within, and the constellations of, particular figures - their so-called 'person fields' - have to be carefully considered in terms of their historical viability, which is always situated in a particular historical context, and in terms of their usefulness for the present-day historian's task of elucidating past practices.

In this chapter, I will introduce another masculine figure, that of the werewolf, and ask in what kind of relationship he stood to both male and female witches (the term 'warlock' is an archaic old-English expression for sorcerer or magician, chosen in my title for its alliteration), ${ }^{4}$ or 
indeed other categories of actual or alleged practitioners of magic. In his hybrid capacity, the werewolf seems, at least, to be related to the shifty sorcerer, but it has yet to be established to what extent. A discussion of werewolf concepts can profit from being framed in terms of questions about early modern masculinity, as well as about notions of sexuality and gender in general. At the same time, this adds even more complexity to an already complicated issue. In the context of the relationship between werewolf and warlock, the following question also arises: Since werewolves were subject to metamorphosis and also operated at the level of metaphor, how far was this also the case when it comes to magicians? At this point, these concerns can merely be raised for future consideration, as they are beyond the scope of this chapter.

Several short introductory remarks on masculinity are nevertheless imperative: it is, as yet, far from being a universal tool of historical analysis, and the results of its study are hardly building up to a possible 'profile' of all early-modern masculinities, as they are predominantly linked to the concepts of honour and violence. ${ }^{5}$ For reasons explained below, masculinity will be seen here primarily as a normative concept: as an instruction, blueprint, and measuring rod of how to behave. Gender theory, in its turn, has still to be confronted with the prospect of proceeding beyond male and female (or combinations thereof), and moving into the third gender of the animal realm, if only from a human perspective. As. will be argued in this chapter, a cultural approach to body and gender has to be genuinely cultural and not secretly materialistic, while at the same time, recognizing that for early modern people biological differences - such as those between male and female, and between human and animal - formed an integral part of their mental outlook.

In contrast to witchcraft historiography, recent reliable academic treatises on werewolves are extremely scanty. This is due both to a lack of interest in them, and a dearth of source material. ${ }^{6} \mathrm{New}$. presentations on the subject also have to position themselves against the many existing interpretations, which are inversely proportional to the research. ${ }^{7}$ Within the boundaries of Europe, werewolves were not omnipresent and readily available for persecution as (alleged) witches were. In other words, the dispersion of the werewolf concept was fragmentary, or at least limited on a temporal and geographical scale. ${ }^{8}$ Most werewolf historiography, nevertheless, neglects this point. One encyclopaedia entry simply summarizes him as 'a murderous cannibal wolf'. Another states that, in some trials, 'it is clearly shown that murder and cannibalism took place'. ${ }^{9}$ The American literary scholar Charlotte Otten, in her turn, puts sexual aggression first, noting that 'trial records of cases of lycanthropy contain detailed accounts of rape, incest, murder, savage attacks, and cannibalism' ${ }^{10}$ Such observations are not based on thorough research, however, but merely on the published accounts of only seven werewolf trials - four from Franche-Comté, two from elsewhere in France, and one Germany. The list of French cases starts with the werewolves of Poligny, on trial in Besançon in 1521, and continues with Gilles Garnier in 1573 (also in the neighbourhood of Besançon), Jacques Roulet of Angers and the 'cannibal' tailor of Châlons (Nicolas Damont) in 1598, and the Gandillon family in St Claude (Franche-Comté) in the same year. It ends with Jean Grenier, who was banished to a monastery by the Parlement (High Court) of Bordeaux in 1603. This last trial, as Adam Douglas notes, 'marked the end of the werewolf fever in the French judicial system', ${ }^{11}$ The German case concerned Peter Stubbe from Bedburg, near Cologne, in 1589.12

The image of the murderous and cannibalistic werewolf already existed when Sabine Baring-Gould published his Book of Were-Wolves in 1865 , in which he referred to all six of the Francophone trials. It was confirmed in 1933, when the self-proclaimed 'Reverend' Montague Summers presented his learned tome The Werewolf to the public. He had found a few trials in the literature that Baring-Gould had neglected. But, apart from the English version of the Stubbe pamphlet, which Summers published in full, he did not reveal much about these new cases and, in subsequent werewolf publications, they were again ignored. Among them was the 1598 trial concerning the 'warlock' Jacques Bocquet, executed with several witches who had shifted their shape to wolves and haunted the wood of Froidecombe' in the Terre de St Claude. ${ }^{13}$

The published details about these trials do, indeed, convey a cannibalistic image. In the translation by Summers, the Poligny werewolves 'Pierre and Michel attacked and tore to pieces a boy of seven years old. An outcry was raised and they fled. On another occasion they killed a woman who was gathering peas. They also seized a little girl of four years old and ate the palpitating flesh, all save one arm'. Giles Garnier slew a young girl and dragged her to a wood where 'he stripped her naked and not content with eating heartily of the flesh of her thighs and arms, he carried some of the flesh to Apolline his wife'. Other victims of Garnier included a girl, a ten-year-old boy and another boy of about 12 years. The tailor of Châlons used 'to decoy children of both sexes into his shop, and having abused them he would slice their throats and then powder and dress their bodies, jointing them as a butcher cuts up meat'. 
Roulet's victim was a boy, who was found 'shockingly mutilated and torn. The limbs, drenched in blood, were yet warm and palpitating'. ${ }^{14}$ Summers had a preference for the last word, whereas Baring-Gould paid more attention to feasting and described the children's flesh as 'delicious', 'eaten with great relish'. The element of shape-shifting was hardly present here, especially in the accounts of Baring-Gould. 'On this occasion,' he wrote of Pierre Burgot of Poligny, 'he does not seem to have been in his wolf's shape.' The men who prevented Garnier from devouring his final victim said that he had 'appeared as a man and not as a wolf'. Of the Châlons tailor, Summers states only that he was convicted 'for lycanthropy' and adds that 'under the shape of a wolf, he roamed the woods to leap out on stray passers-by and tear their throats to shreds'. ${ }^{15}$ Finally, in Baring-Gould's version of the interrogation of Roulet, the man stated that he had killed and eaten a child when he was a wolf but, when questioned about the way he was dressed and about his head, answered that everything was the same as his interrogators could observe. ${ }^{16}$ In other words, his humanity - and human responsibility - was emphasized, rather than his beastly traits.

Although the sources allow for these differences in presentation of the figure of the werewolf, they primarily reflect the divergent interpretation of the two authors. Both were connected to the Church, but Summers - as a defrocked Anglican and a pretend Roman Catholic priest $^{17}$ - placed most emphasis on the influence of the Devil, while the Devonshire parson Baring-Gould emphasized the human aspects of his werewolves. Only by quoting the early-sixteenth-century wolf sermon of the German preacher Johann Geiler von Kaisersberg at the very end of his book did Baring-Gould indicate that 'man must turn to God when He brings wild beasts to do him mischief'. Baring-Gould pointed out that Geiler, 'puts aside altogether the view that [werewolves] are men in a state of metamorphosis'. The Book of Were-Wolves bears this out. It might contain summaries and editions of most of the then available werewolf texts, but there are also chapters that only discuss murderers who were never described as 'werewolves', thus making it clear that its author regarded lycanthropy mainly as an extreme form of man's 'love of destroying life'. Werewolves were insane: 'the naturally cruel man, if least affected in his brain, will suppose himself to be transformed into the most cruel and bloodthirsty animal with which he is acquainted'. ${ }^{18}$

Summers thought that Baring-Gould wrote 'graphically and with vigour' and did not shy away from the 'terrible truth' of the subject, but that he had also inserted 'a great deal of extraneous matter'.19 Against the popularizer Baring-Gould, Summers could easily claim the weight of authority: The Werewolf is littered with (untranslated) quotations in French and Latin. Summers, however, accepted the reality of the Devil and did not see any ground for questioning the statements of tortured people - in his view they were already 'wicked' and 'horrible'. Discussing the opinions of the French lawyer Jean Bodin, who had included material on werewolves in his hugely influential demonology, De la démonomanie des sorciers in $1580,{ }^{20}$ Summers noted: 'it is very certain by the common consent of all antiquity and all history, by the testimony of learned men, by experience and first-hand witness, that werewolfism which involves some change from man to animal is a very real and a very terrible thing'. In his bombastic style, Summers wrote as if taking part himself in the werewolf debate that raged around 1600. Bodin's theory was based on sound Christian doctrine, Summers found, whatever his enemies might have read into it. One of Bodin's critics, Jean de Nynauld, was a 'heretic' who contradicted 'the sense of the Scripture'.21 This makes it difficult to consider Summers' book as anything more than a jumble of werewolf materials; his account of early modern debates is too biased to be of much historiographical use. He fell into the trap of anachronism and, as a psychiatrist observed in the late-twentieth century, he 'would have made a superb exterminator of hundreds of fellow humans if he had just been born a few centuries earlier'. ${ }^{22}$ But Summers would have had difficulty in holding his ground in early modern times. Certainly, in his position on the werewolf, he outdid the Roman Catholic demonologists, as his assessment tried to combine irreconcilable views: 'By the force of his diabolic pact he the witch] was enabled, owing to a ritual of horrid ointments and impious spells, to assume so cunningly the swift shagge brute that save by his demoniac ferocity and superhuman strength none could distinguish him from the natural wolf ${ }^{\prime 23}$ With this conclusion, Summers reduced a complex historical debate to a personal concoction.

Baring-Gould, who rarely names his sources, seems to have made ample use of French and, to a lesser extent, German publications. ${ }^{24}$ His account of a recent case of desecration of graves in Paris was taken straight from a French report. 25 The descriptions of the early modern cases ultimately derive from demonological publications, such as De prestigiis daemonum by the Rhineland physician Johann Wier, Discours exécrable des sorciers by the Franc-comtois judge Henry Boguet, and Incrédulité et mescréance du sortilège by Pierre de Lancre, a jurist and a member of the Parlement of Bordeaux from 1582 to 1616 . Pamphlets provided additional data, such as the one about Gilles Garnier that was 'circulated through all the cantons of France, Germany and Flanders', as a contemporary remarked. ${ }^{26}$ 
Or A True Discourse Declaring the Damnable Life and Death of One Stubbe Peter, which appeared in London in 1590 . The contents of these newssheets had also found their way into the early modern demonologies. ${ }^{27}$ Summers, who translated several, consulted the latter directly. But since demonologists had their own agenda, the use of their works did not necessarily ensure accuracy. Accounts of witch-trials that started to appear in the course of the nineteenth century could have provided a counter-balance, as they sometimes incorporated records of werewolf persecution. But they were mainly in German (which Summers shied away from) and, as the compiler of witchcraft texts Henry Charles Lea remarked on the basis of the eighteenth-century Bibliotheca sive acta et scripta magica: 'wer-wolves are rarely found in the witch-processes. Of a hundred men, only three or four are accused of or confess to it'. ${ }^{28}$ Witch-trials primarily involved women.

Modern popular accounts reduce the seven werewolf cases to one or two. For instance, Gordon Stein discusses Grenier and Roulet, and then remarks: 'There are several other cases similar to these, but they need not be mentioned, except in passing later'. Keith Roberts thought that 'the history of Stubbe Peter is typical for the reports about werewolves at that time'. ${ }^{29}$ These conclusions are premature. Werewolf trials might have been relatively few and far between, but research into witch-trials has (especially in Germany) provided enough werewolf cases to develop a different image next to the one of the cannibal. In fact, a precise reading of the Peter Stubbe case (or Stump, to revert to his German name) already supplies an alternative.

\section{II}

In Germany, werewolf trials were introduced with the Stump case of 1589, situated in the area between Aachen and Cologne. Writing his demonology De prestigiis daemonum a few decades earlier, Johann Wier had not reported any regional werewolves, and had to suffice with referring to the Poligny case from Franche-Comté and to Livonian werewolves. ${ }^{30}$ The accounts of the werewolf Peter Stump were constructed out of a mixture of legal concerns and stories that had spread from eastern France, particularly Franche-Comté. ${ }^{31}$ Peter Stump was executed on 31 October 1589 in Bedburg (near Cologne). Pamphlets about his case were printed in Augsburg and Nuremberg, and in Denmark, Antwerp, and London. ${ }^{32}$ It was the London edition of 1590 that single-handedly created the image of the Renaissance murderous and cannibalistic German werewolf, and the case was subsequently branded as 'the most celebrated European werewolf trial', ${ }^{33}$ merely because the pamphlet was the main English text available. The Stump case, nevertheless, calls for caution. A German historian has even expressed serious doubts about whether the pamphlets actually referred to an historical event, one reason being that there are no surviving trial sources. ${ }^{34}$ Only two other contemporary reports have been found so far, one by the Cologne pastor Hermann Weinsberg. In his diary entry for 1589 , Weinsberg wrote that rumours had been circulating about the case during the entire summer, and then he started citing from a pamphlet: a peasant had lain with a female devil for 25 years and, in between, with his own daughter, denoting incest. He had a belt, and when he put it on he became a werewolf, but he kept his own mental faculties. In wolf's shape he had devoured 13 children, among them his own son. To punish him, hot irons were pressed into his body, his arms and legs were broken, and he was finally decapitated and burned. Weinsberg based this part of his account on a German text, possibly the pamphlet from Augsburg or a similar one. In his opinion, the murders and incest perpetrated by Stump fully justified the punishment, but Weinsberg was not so sure about the 'witcheries' (meaning the shape-changing), as he could not believe everything that was told and retold about them. Who could say whether it was fraud or fantasy, or not? ${ }^{35}$

Two elements in this account support the existence of an actual trial: people had been talking about it, as far as can be ascertained, before any pamphlet had been published. And there is the neat legal point, derived from Bodin, that Stump's 'mind and reason had remained intact', ${ }^{36}$ which is not mentioned in any of the other surviving pamphlets, but betrays the presence of lawyers. It was the first German werewolf case, ${ }^{37}$ and the French paradigms of murder, cannibalism, and deviant sexuality it echoed would not be repeated in the subsequent German werewolf cases in this combination. On the other hand, there is no mention of ointment; instead, a belt is featured, which does not occur in the reports from Franche-Comté (if the werewolves there used anything similar, it was a whole skin). Another distinctive German detail is that of a pole with a wooden wolf on top erected at the place of execution.

The other contemporary report was by the Dutch chronicler Arnoud van Buchell. On one of his journeys to Germany, he met a member of one of the ruling families of Cologne, who had witnessed Stump's execution and told him that the werewolf had once been his servant. ${ }^{38}$ But the possibility that these pamphlets reveal a genuine event does not make them less sensational and fantastic. The news-sheet from Nuremberg added the (French) story about Stump being recognized by his missing hand after 
the wolf's paw had been cut off. This latter incident was absent from the London version, which otherwise seems to have included every known rumour conveyed to the printer by several letters from Germany. In the London account, the werewolf is said also to have copulated with his own sister, and deflowered several girls before murdering them. When humans were no longer available then like a cruell and tirannous beast he would woorke his cruelty on brut beasts in most sauadge [savage] sort, and did act more mischeefe and cruelty then would be credible' ${ }^{39}$ This could be read as cannibalism, although it can also suggest 'consumption' in the sexual sense. And, if Stump committed sexual acts, his 'working on brute beasts' points to no less than bestiality. One fragment even reads like a forerunner of the wolf from Red Riding Hood:

he was straight transformed into the likeness of a greedy deuouring woolf, strong and mighty, with eyes great and large, a mouth great and wide, with most sharpe and cruell teeth, A huge body, and mightye pawes.

The story about Stump's arrest provides another narrative element in the London pamphlet. While hunters were chasing a wolf, they suddenly found a man, walking with a stick, where they had just seen the wolf. In 1573, a similar story was reported from Dole by a German student. ${ }^{40}$ In its totality, the Life of Peter Stubbe represents an inversion of Christian family values and, more specifically, a subversion of the preservation of progeny. It opens with the admonition that those who forsake the Lord and despise 'his proffered grace' enter the 'path to perdicion and destruction of body and soul for euer'. A decapitated Stump is shown tied to the stake between his daughter and concubine, as a mockery of the crucifixion scene.

It seems, nevertheless, strange that Stump's werewolfery could have remained undetected for so long, the more so since his name was a nickname which literally meant 'stump', and translated into English as 'stub' or 'truncated' (as a regional dialect term for 'werewolf', it was still current four centuries later). If his nickname referred to his deviant sexuality, then it ironically stood for his short penis (some of the French werewolves had short 'tails' too). ${ }^{41}$ But according to the stories, the belt provided him with a disguise 'wherby he might liue without dread or danger of life, and vnknown to be the executor of any bloody enterprise'. Thus, he could walk around in the streets of Cologne, in Bedburg, and in his hometown Erprath 'very ciuilly as one well known to all the inhabitants thereabout' without arousing suspicion. Almost a quarter of a century later, the notion of the werewolf's invisibility reappeared in Cologne; ${ }^{42}$ it had obviously been kept in circulation since 1589. It is, nevertheless, debatable whether or not it constituted a more or less traditional local trait; it could also have been taken from Bodin's demonology. ${ }^{43}$ The contrast between the werewolf's name and the peasant Stump's appearance in nearby towns indicates that his sexual deviance was more or less tolerated on his home-ground, and that at his trial his crimes were probably aggravated and augmented. They acquired narrative properties as they were grafted onto French concepts - the 1573 Garnier case, with its cannibalism, had also been distributed in Germany. Only in this way does it become possible to reconcile the traces of a legal event with the multitude of stories.

In the eyes of his judges, Stump was not a man, and they underlined this by having his body taken apart by the ritual of execution. This does not imply that they considered him feminine, such as witchcraft theory deemed about sorcerers; ${ }^{44}$ it is far more likely that they saw him as a werewolf, the animal they were so keen to redefine. This was moreover shown by the erection of a kind of wolf statue on top of a wooden pole at the place of execution. Masculinity was not just displayed by the judges in their somatization of legal violence and their brutal exercise of power. The event was public - it was a stage on which, next to the criminal, the local aristocracy and other male authority figures paraded.

\section{III}

Understanding the Stump case in terms of masculinity involves a slightly different approach from that adopted in most other histories of manhood. Studying past masculinities amounts for the most part to juggling with constructs. As a cultural entity, encompassing notions of proper male behaviour, masculinity was fluctuating, with the speed and amount of change depending on the particular times. It was also defined within specific groups, regions, and denominations. It was related to age, in the sense that there were clear delineations between young boys, adolescents, married men, and widowers (even though it is debatable whether the concept of masculinity should be applied to formative phases). It was, presumably, also a matter of class, or whatever social hierarchy was current at the time. Approaching masculinity from a normative perspective, or as 'the approved way of being an adult male in any given society', ${ }^{45}$ implies distancing ourselves from seeing it as everything that men did. For the latter, essentially biological, point of view can lead to peculiar observations, such as the idea that particular 
forms of masculinity would be 'disruptive' of 'patriarchal order', thereby creating an artificial 'paradox of masculinity' ${ }^{46}$ No society has ever been without the antagonism between prescribed and actual (or merely imagined) behaviour; what makes 'masculinity' worthwhile as a tool of historical analysis is precisely how people positioned themselves, or were positioned, within this field of tension. If actual expressions of what a man should be were different between one group, or even individual, and another, then it would make more historical sense to treat them as different masculinities, possibly in hegemonic order, ${ }^{47}$ rather than as conflicting aspects of one overarching, non-historical 'masculinity'. Stump, although clearly a man, was not portrayed as a paradigm of masculinity; instead, he represented everything a man should not be. However, his case also showed the importance of family values and the male responsibility towards the next generation.

While, for the historical actor, masculinity would have been a matter of learning, and of acquiring a sense of what was expected at particular times and places - not only of men, but of women too - for the historian it amounts to painstakingly reconstructing its parameters, details, and variation. Early modern Europe possessed written systems of law that were meant to indicate boundaries of acceptable conduct, and to curb excessive behaviour. These were regionally different but also possessed common denominators, derived as they were from Roman codices, Saxon legislation, and Canon law. ${ }^{48}$ On a practical level, sanctioned masculinity showed itself in the pursuit of war, commerce, politics, and learning. These are certainly the subjects of male history predating the gender turn, but they can also be studied as acts in which masculinity was asserted and tested. Research, however, has concentrated on unearthing unwritten rules of gendered behaviour, focusing on the relatively 'soft' themes of family, sexuality, and 'magical' communication..$^{9}$ In both cases, there is a severe danger of, yet again, overlooking women. ${ }^{50}$ It is even more important, however, to recognize potential masculinity in women's discourses and femininity in men's, so as to untie the concept of gender from biological sex. Yet it is difficult to distinguish femininity in werewolf cases.

\section{IV}

In 1595 the provincial Court of Utrecht in the Dutch Republic conducted witch-trials against a number of inhabitants of Amersfoort, and introduced the werewolf accusation. The notion of conducting a criminal trial against a werewolf could have reached Utrecht in several ways.
It might have come through the pamphlet about the Stump case: the local University library there still has a copy. Another possible route was through the chronicler Arnoud van Buchell, who lived in Utrecht and who travelled along the Rhine and discussed werewolves with the Count of Nassau. ${ }^{51}$ Or it might have come directly through the Count, who was closely related to the Dutch stadholders. Whatever route the information had taken, in the Dutch context, the addition of the werewolf accusation to the witch-image was an audacious move by the Utrecht Court, since the High Council in The Hague had just moved in the other direction by declaring the water ordeal in witch-trials illegal and freeing an accused witch (a point ignored in Utrecht as well). Since it is possible to compare the earlier witnesses' testimonies from the municipal court of Amersfoort (where the accused had been tried before) with the testimonies and confessions made before the Court in Utrecht, the absence of werewolves in Amersfoort can be established. In Amersfoort, a man called Volkert Dirksz had been accused of bewitching horses, and had been compelled to bless them to lift the bewitchment. Although having married into a family of witches, defined in the female line, Volkert's witchcraft was situated in the male sphere of influence. ${ }^{52}$ When his daughter was interrogated, she confessed to dancing on the bleaching ground just outside Amersfoort with her female relatives, all in the shape of cats. In Utrecht, Volkert's sons were drawn into the proceedings and wolves were mentioned for the first time. Elbert, aged 13, told the councillors that:

barely half a year ago, he, his father and Hessel his brother in the presence of his father's lord and master, of whom he did not know how he was dressed, had all been changed into wolves, on a field near Bunschoten at the Haar, in a dark night, and that he and his brother rounded the cattle up, without doing anything else, to have them bitten in the throat by his father, but that he and his brother had not bitten [the cattle].

Elbert's brother related a confusing story of how he had been with his godmother when the Devil had visited them in the shape of a naked black man, who had given him a piece of black leather and a piece of black woollen cloth with pins. The Devil had flown up the chimney with him into another room and had also fetched the red cat [a woman]:

and in that room they danced together; after the dance the evil one said to the woman, you dirty beast, now you will come with me, and he bound a hairy belt around her body and when that was done 
the red cat changed into a wolf, and the evil one flew with him and the red cat out of the chimney to Eemland in the field, where he rounded up the animals, which were then bitten by the evil one and the red cat, both in the shape of wolves

The court also found witnesses who asserted that the brothers had admitted to them that they were the wolves that had killed their cattle. ${ }^{53}$ These accounts - related by children, and somewhat vague and confused - indicate the peripheral position of the Dutch werewolves in relation to the developing German centre. In the Northern Netherlands, the new werewolf concept was added to the existing image of the male witch, whether it concerned the bewitching of animals within the male domain, or the acquisition of wealth and power.

These last two characteristics defined male witchcraft in large areas of Western Europe to a significant extent, although the picture was confused in the seventeenth-century political trials, when men were forced to confess to attendance at the Sabbath, or to having made a pact with the Devil without having been previously reputed as a male witch. When Briggs writes, however, 'that there is little or no sign that the male witches had been anything but masculine in their behaviour', he is referring to a different masculinity than I favour here. ${ }^{54}$ When they had adhered to norms of manliness, male witches would not have been prosecuted; they found themselves in a witch-trial precisely because they had somehow crossed masculine boundaries. Male cunning folk could also end up in criminal trials, which also signals that they overstepped certain norms, and that their witch-finding or recovery of stolen goods was not seen as particularly manly - at least, not by the authorities. ${ }^{55}$ This did not necessarily make them male witches, however, unless some of their professional identifications of (mostly female) witches had backfired and they themselves had been accused of bewitchments. ${ }^{56}$ On an everyday level, the bewitching or enriching male witch was almost as current as his female counterpart, a point supported by the as yet sparsely researched slander trials. ${ }^{57}$ During the process of turning a local suspicion into a persecution, however, most of the male witches, together with their specific brand of witchcraft, were filtered out:

\section{V}

If the Stump pamphlet was meant to sensitize people to werewolves, it generally succeeded; if it was meant to encourage them to hunt the beasts, it failed. No werewolf trials were initiated in southern Germany,
England, or Denmark, despite the publication of Stump pamphlets in these places. The late-sixteenth-century werewolf trials conducted in Protestant Nassau, within a hundred kilometres of Cologne, were only partially influenced by the narrative from Catholic Bedburg, since the Protestants had to reinvent the werewolf yet again. ${ }^{58}$ Only to the west, in the Catholic Southern Netherlands, do we find both a version of the pamphlet text and corresponding werewolf trials. Although it is not known what the first werewolf in 1592 in Mechelen was accused of precisely, in 1598 another one was indicted for biting little children 'behind their ears, in their side, under their armpits and finally in the throat'.59

The Stump case might have acted as a paradigm and catalyst for a number of subsequent werewolf trials in the region, although its constructed werewolf was regularly adjusted to fit both local considerations and imagery. In the Netherlands, the same combination of male witch and werewolf as had been tried out in Utrecht surfaced a few months later in Arnhem, at the trial of Hans Poeck (officially known as Johan Martensen van Steenhuijsen). This man was not tortured and confessed voluntarily after staying afloat during the water ordeal he himself had demanded. It is, nevertheless, clear that he did answer questions, some of them leading. He claimed that, about three years earlier, after his leg had been injured by a horse, he had met a man walking on the dyke. When asked for food, the man had said: 'I will give you plenty if you will do my will'. Hans had hesitated but when the exchange was repeated several times - in the meantime, two women had passed by he finally consented to renounce God. At that moment, he had felt something like hot or warm water on his face, the sign that his chrism was being removed. The Evil One - for Hans had encountered no other but him - had then given him a piece of cloth, saying: 'As long as you have this, you will succeed in everything'. Next, Hans confessed that he had been 'walking as a wolf' for three years. After turning into a wolf he was still capable of human judgement, but could not speak.

This last element of his confession points again to Bodin's theory about the preservation of human intelligence and responsibility. The rest contains a.combination of his bewitchments and his experience as a werewolf. Poeck had bewitched a woman innkeeper and several horses by hitting them with the piece of cloth given to him by the Devil. When he put it on his own head, he became a wolf. He claimed to have a belt (although this was probably in answer to a question), but he had hidden it in some house, in a hole behind a bed. Often eight or ten wolves had crowded round him, among them the Devil, likewise in wolf's shape. Once the Devil, still as a wolf, had thrown him into a ditch because 
Hans did not want to bewitch animals for him. Another time the Devil had frightened his horses to such an extent that he had had to continue walking with him, again in the form of a wolf. They had gone to a certain place and, afterwards, he had returned to the horses, and there he was freed by two men who happened to pass by. ${ }^{60}$ Once more, the nickname is the clue to the meaning of 'werewolf': poe(c)k derives from the Dutch verb poekelen, to carry (something or someone) on one's back (pukkel denotes a kind of rucksack). Hans Poeck was thus a man whom other people carried on their back. This indicates a homosexual act, as in all probability do his encounters with the Devil. His was the last werewolf trial in the Northern Netherlands, but slander trials show that the combination of werewolf and male witch was an insult in the eastern provinces throughout the entire seventeenth century. In a number of cases, this included the werewolf's connotation with sexual deviance.

In the course of a witch-trial in 1609, in Horst (near Gladbeck), a whole family was subjected to the water ordeal. When the father stayed afloat, he ascribed it to the incest he had committed, not to witchcraft. But when he heard that his children had confessed to being witches, he admitted to being a werewolf. The Devil, whose name was Federbusch (crest of feathers), had persuaded him to denounce the Holy Trinity and had fornicated with him (in other trials against men, the Devil is described as a woman, first). The Devil had also been with him at a dance, and had given him a belt. After this, he confessed to having 'bitten' several cows and foals. As before in Bedburg, a pole with a wooden wolf on top of it was erected at the place where he was strangled and burned. ${ }^{61}$ The trial of Peter Kleikamp from Ahlen (south east of Münster) even started with an indictment for sodomy. Because the prosecutor could not uphold this, he switched to a witch-trial, for which less stringent rules of evidence applied. In this way, Kleikamp was made to confess, among other things, that in the form of a wolf he had 'bitten' a calf and 'shamed' a young ox. He had only six hours in which he could 'walk' as a wolf. More witch-like was the part of his confession where he admitted that he and some others had anointed themselves and then flown in the form of ravens, a detail that his interrogators might have borrowed from a description of a witch-trial in Liège. ${ }^{62}$ In a case from Strasbourg in 1633, concerning a 16-year old boy from Molzheim, we find similar elements. The boy was accused of having:

killed many cattle. Among others he had sat on the back of a cow in the shape of a raven and had pecked at it and eaten of it till it died, and as a fox he had hung on the tail of another [cow], till it had jumped to its death. He had made several maidens pregnant and had committed sodomy with a sheep while he was in the shape of a dog and with a pig while he was in the shape of a wolf. ${ }^{63}$

In the commentary on her compilation, Otten based her notion of sexuality on the Stump case, which she edited and reprinted; she emphasized that 'Stubbe' 'confessed to committing incest with his daughter and sister'. In his earlier book on 'the occult', Wilson, referring to the Gamier and Stubbe cases, stated that 'sexually frustrated peasants identified with werewolves'. ${ }^{64}$ Although both authors present little further evidence, the role of sexuality was explicit from the start when the Poligny werewolves told their judges in 1521 that, when they were wolves, they copulated with female wolves, which gave them as much pleasure as with women (it is unclear whether here, as in Latin, the same word was used for bitches and whores). In the Châlons case from 1598, the tailor 'abused' the children - in all likelihood, sexually - before killing them, and, in 1599, the werewolf Verjuz in Franche-Comte was said to have committed incest with his mother. ${ }^{65}$ A girl who acted as a witness in the trial against the teenager Jean Grenier in 1603 stated that she had been attacked by a wild animal 'which was fatter, but shorter than a wolf and which had a short tail'. Later, Grenier boasted that he was that animal, 'and that if he had managed to get her on the ground he would have given her a good bite'. ${ }^{66}$ A historian has called this a 'sexual phantasm', and I am inclined to agree with him. ${ }^{67}$ The 'short tail' will have referred to the boy's penis and the 'bite' to sexual intercourse.

\section{VI}

Some pamphlets display a troubled relation with historical events. Two years after the Stump story, an even more sensational report appeared in Augsburg, supposedly describing events in Jülich, only a few kilometres from Erprath, where Stump had committed his crimes. It related the story of more than 300 women who had, supposedly, changed into wolves and killed many men, boys, and cattle. Of them, 24 were discovered because a boy had found his mother's belt, tried it on and become a werewolf himself. When this frightened the other children, the neighbours gathered to get rid of the wolf. But the boy implored them not to harm him; he had only put on the belt by accident, and his mother had done it every day. She was subsequently imprisoned and tortured, and confessed to having accomplices. In those days the execution of two dozen women for witchcraft was quite plausible and, when all the 
convictions from the area from Osnabrück to Trier are added up, the figure of 300 does not appear excessive either. ${ }^{68}$ The episode about the boy, however, was clearly a legend that survived into the twentieth century, ${ }^{69}$ and the idea of such an extraordinary number of female werewolves was pure fantasy. The Augsburg printer who published the pamphlet was known for his sensationalism, and he probably wanted to match the success of his colleague who had printed the Stump pamphlet. Only very occasionally was a woman accused of being a werewolf. Moreover, the pamphlet about Jülich is extremely sexist: it ascribes a male trait to a group of women, thus rendering them less female, and describes how these manly women attacked and devoured men, and 'sucked up their blood and ate their brains'.

The existence of some of the female German 'werewolves' might only have been due to the fact that, during a witch-trial, a woman was forced to admit to having changed shape into an animal form, or when reference to a wolf's shape was simply added on to those of the more female cats and hares by witnesses or interrogators. If the first two women denounced in 1630 in Oberkirchen, some 60 kilometres north of Dillenburg, provide any evidence of the concept of a female werewolf outside the context of a witch-trial, then their case suggests that it seems to have been independent women who came under suspicion. ${ }^{70}$ This was probably also the case in 1590 in Lower Hesse, where a woman was accused of having bewitched a cow. She worked her farm on Sundays and, apparently, had no husband. The neighbours avoided her, because she was said to be 'doing her foul work as a tearing wolf at night with her children'.71 This woman might not have been called a werewolf, but her behaviour was certainly compared to a wolf. The majority of woman who were accused of being werewolves, however, were considered to be so because the rule of place was applied to them: they had been seen where, just before, a wolf had been spotted. This was one of the recognized shape-shifting mechanisms ascribed to witches, usually in connection with shapes such as cats or hares; notwithstanding a reference to it in one of the Stump pamphlets, there is no evidence, as yet, that it applied to men. The motif was already present in Lucerne in 1489 , when a woman appeared in the wrong place at the wrong time. ${ }^{72}$ In 1614, a woman was on her way back from the market in Wilz (in the Eifel region of western Germany) where she had sold some cows when she saw one of her neighbours in the moonlight. When she asked her how she had got there and mentioned the name of Jesus, her neighbour had disappeared and a wolf stood in her place and had approached the horses. The woman had driven off and not seen anything further, but later she had become ill. This neighbour had also been encountered as a cat. A similar story was told 40 years later in Sauerland, in the Electorate of Cologne. A horse had been attacked by a wolf, and it was suggested that a woman neighbour had not been far away from it, and was possibly the wolf herself. Again, in 1668, a woman appeared where a wolf had been spotted before, and the woman who saw her was so frightened of the wolf that she miscarried. ${ }^{73}$ Yet other women were deemed to have attacked cattle in wolf form. ${ }^{74}$

Overall, however, werewolves only constituted a tiny minority among the witches, and the handful of female werewolves are, in their turn, a tiny minority among the predominantly male werewolves. It might just be possible to scrape together 300 (predominantly male) werewolves in the whole of Europe over a period of 200 years; the suggestion in the 1591 pamphlet that this number of female werewolves would have been prosecuted in one year is absurd. Most of the few female werewolves were accused later, after the male image had become established by the waves of witch-trials between 1590 and 1630. But one should still be aware of regional variation. In Mecklenburg, in the north east of Germany, a different picture emerges. Trials only started there in the second half of the seventeenth century, and the werewolves constituted less than one per cent of all those accused. ${ }^{75}$ Here, however, a substantial portion of them were women.

\section{VII}

Men such as Stump, Poeck, or Kleikamp might have asserted their own idea of manhood in their sexual exploits and, especially when their behaviour had been more or less tolerated for a while locally (nicknames do need some time to settle), ${ }^{76}$ the new trials certainly signalled a tougher regime. Officially, anal sex was not allowed, as it ran counter to the ideas of sexual union for the purposes of reproduction, which could only take place within a sanctioned marriage. The criminalization of female witchcraft expressed similar concerns with productivity, as witches were usually accused of hampering growth (in humans, animals, and crops), and of interfering with processes of maturation. ${ }^{77}$ Whereas female witchcraft was seen in terms of negative femininity, which in early modern society amounted to negative female sexuality, male witchcraft was not focused primarily within the sexual domain, but was deemed to run counter to those aspects of masculinity that were defined by honour. Far from being an individual characteristic, honour set out man's relation to the different male communities of which he 
was part or with which he had dealings. Male witches exercised unnatural power that some considered feminine, but that mainly stood in opposition to communal codes of the distribution of wealth. Sexuality seems to have been absent in male witchcraft, at least in terms of how it was seen on an everyday level.

Apart from the occasional overlap in marginal areas such as the eastern Netherlands (although even there the juxtaposition of the terms for male witch and werewolf did not have to make them synonyms), werewolves and male witches thus occupied different conceptual niches. In short: werewolves usually did not bewitch anything, neither were they accused of enriching themselves in unbecoming ways. It could be argued that werewolves and male witches merely expressed different negative aspects of masculinity; here, I want to suggest that the concept of a werewolf exceeded masculinity and femininity, and constituted a third gender, indicating those humans who had gone beyond humanity and had entered the animal realm.

A detailed discussion of human-animal intersection would obviously make a separate paper, and the possible notion of an 'animal' gender has to remain tentative. A non-man, who did not equal a woman, was possibly too abstract a concept, however; traditionally the wolf image did represent the man - or, more specifically, the sexual criminal - outside society. Someone who was an animal was not part of humanity. The figure of the werewolf also came to combine the animal body and animal sexual behaviour - such as back-riding (as in the Poeck case), or sodomy in general. ${ }^{78}$ Putting on a belt separated the upper from the lower half of the body, thereby stressing the sexual. When that belt was made of animal skin (although substitutes were known too), it referred explicitly to bestial sexuality.

Moreover, the conceptual relation between animals and deviant sexuality will have been more current not only in werewolves, but also, for example, in satyrs, another kind of human-animal hybrid who signified excessive sexual lust. ${ }^{79}$ Goats had their connotations with the male 'sins of the flesh' as well, in precisely the same intellectual environment in which clerics and sorcerers moved, and where initiates were adorned with goat attributes, for instance. ${ }^{80}$ And not only men could become animalized. Stories about dancing cats circulating in the sixteenth-century Netherlands, to mention another instance, pointed at sexually loose women. The notion of animalization of, in this case, incest was also present in the story of the princess who was desired sexually by her father and escaped clad in animal skins - either bear, donkey, or a mixture of different species. ${ }^{81}$ In addition to wolves, goats, and men, future research has also to explore similar stories and ideas about shape-changing women. In all these different instances, animal metamorphoses were comprehended as metaphors of sexual deviancy. Possibly, it even concerned more than mere metaphors, since the animal skins indicated that the wearer's body had taken on animal characteristics in an act of animal 'drag' that fused with the wearer's human identity.

\section{Notes}

1. For a recent discussion, see $\mathrm{F}$. Klaassen, 'Learning and masculinity in manuscripts of ritual magic of the later Middle Ages and Renaissance', Sixteenth Century Journal, 38 (2007), 49-76. For a more balanced view, see N. Cohn, Europe's Inner Demons: the Demonisation of Christians in Medieval Christendom (London, 2005; reprint of the revised 1993 edition), 118-43.

2. Cf. W. de Blécourt, 'The Return of the Sabbat: Mental Archaeologies, Conjectural Histories or Political Mythologies?', in J. Barry and O. Davies (eds), Witchcraft Historiography (Basingstoke/New York, 2007), 125-45.

3. P.G. Maxwell-Stuart, Wizards: A History (Stroud, 2007), 11.

4. For a different slant on the classic children's books by C.S. Lewis, see N. Gaiman, Fragile Things: Short Fictions and Wonders (London, 2006), 237-50: 'The Problem of Susan'.

5. Cf. G. Schwerhoff, 'Starke Worte. Blasphemie als theatralische Inszenierung von Männlichkeit an der Wende vom Mittelalter zur Frühen Neuzeit', in M. Dinges (ed.), Hausväter, Priester, Kastraten. Zur Konstruktion von Männlichkeit in Spätmittelalter und Früher Neuzeit (Göttingen, 1998), 237-63.

6. For an outdated summary of the scholarship, see P. Dinzelbacher, 'Lycanthropy', in R. M. Golden (ed.), Encyclopedia of Witchcraft. The Western Tradition, vol. III (Santa Barbara, CA, 2006), 680-2.

7. Cf. W. de Blécourt, 'A journey to hell: Reconsidering the Livonian "Werewolf"', Magic, Ritual, and Witchcraft 2 (2007), 49-67.

8. See R. Briggs, The Witches of Lorraine (Oxford, 2007), 123-6.

9. See 'Werwolf', in C. Rose (ed.), Giants, Monsters and Dragons (Santa Barbara/ Denver/Oxford, 2000), 391; and 'Werewolf', in L. A. Shepard (ed.), Encyclopedia of Occultism and Parapsychology (Detroit/New York/London, 1991), 1797. The last quotation is from L. Spence, An Encyclopedia of Occultism (London, 1920), 426 .

10. C. F. Otten, A Lycanthropy Reader: Werewolves in Western Culture (Syracuse, 1986), 51. Otten's approach is literary rather than historical; cf. her latest compilation, The Literary Werewolf: An Anthology (Syracuse, 2002).

11. A. Douglas, The Beast Within: A History of the Werewolf (London, 1992), 149.

12. See the summaries in R. F. Robbins, The Encyclopedia of Witchcraft and Demonology (Nèw York, 1959), 212, 233-5, 324, 489-90, 537-8.

13. M. Summers, The Werewolf (London, 1933), 229-30.

14. Summers, The Werewolf, $224,226-7,230$.

15. S. Baring-Gould, The Book of Were-Wolves (London, 1865) 73, 81, 78; Summers, The Werewolf, 230.

16. Baring-Gould, The Book of Were-Wolves, 83-4. 
17. On Summers, see J. Wood, 'The Reality of Witch Cults Reasserted: Fertility and Satanism', in Barry and Davies (eds), Witchcraft Historiography $76-85$.

18. Baring-Gould, The Book of Were-Wolves, 266, 131, 145.

19. Summers, The Werewolf, xi, 103.

20. Bodin's influence at the court of Laon, where he was employed, was negligible, on the other hand; cf. C. Opitz-Belakhal, Das Universum des Jean Bodin. Staatsbildung, Macht und Geschlecht im 16. Jahrhundert, (Frankfurt am Main and New York, 2006).

21. Summers, The Werewolf, 76-7, 98-9.

22. R. Noll, Vampires, Werewolves and Demons: Twentieth-Century Reports in the Psychiatric Literature (New York, 1992), 86.

23. Summers, The Werewolf, 123.

24. Such as F. Bourquelot, 'Recherches sur la lycanthropie', Mémoires et dissertations sur les antiquités nationales et étrangères NS 9 (1849), 193-262; R. Leubuscher, Uber die Wehrwölfe und Thierverwandlungen im Mittelalter. Ein Beitrag zur Geschichte der Psychologie (Berlin, 1850); W. Hertz, Der Werwolf. Beitrag zur Sagengeschichte (Stuttgart, 1862).

25. Baring-Gould, The Book of Were-Wolves, 255-60, from Annales médico-psychologiques. Cf. C. Crowe, 'The Lycanthropist', reprinted in P. Haining (ed.), Werewolf: Horror Stories of the Man-Beast (London, 1987), 13-9.

26. Le Loyer in Discours des spectres (1608), 140; cited in Hervé Campangne, 'Arrest memorable contre Gilles Garnier pour avoir en forme de loup-garou devoré plusieurs enfants et commis autres crimes: Métamorphose et commentaire dans une lettre de Daniel d'Auge', Nouvelle revue du seizième siècle, 15 (1997), 343-57, especially 345 .

27. Jean Bodin, On the Demon-Mania of Witches, translated by Randy A. Scott (Toronto, 1995), 122; Martin Del Rio, Disquisitionum magicarum libri sex, (Louvain, 1599), 190 (not included in the English translation), cf. Investigations into Magic, edited and translated by P.G. Maxwell-Stuart (Manchester and New York, 2000).

28. H. C. Lea, Materials towards a History of Witchcraft (first published in 1939; New York/London, 1957 edn), 941; cf. Hertz, Der Werwolf, 71

29. G. Stein, 'Werewolves', in: The Encyclopedia of the Paranormal (Amherst, NY, 1996), 809; K. Roberts, 'Eine Werwolf-Formel. Eine kleine Kulturgeschichte des Werwolfs', in U. Müller and W. Wunderlich (eds), Dämonen, Monster, Fabelwesen (St. Gallen, 1999), 565-81, especially 574.

30. E.-D. Güting, 'Michel Beheims Gedicht gegen den Aberglauben und seine lateinische Vorlage', Forschungen und Berichte zur Volkskunde in Baden-Württenberg, 3 (1974/1977), 197-220, especially 208 (with thanks to Elmar Lorey).

31. On the werewolf trials there, see R. Schulte, Man as Witch. Male Witches in Central Europe (Basingstoke, 2009), 8-18, 23-31.

32. E. M. Lorey, Henrich der Werwolf. Eine Geschichte aus der Zeit der Hexenprozesse mit Dokumenten und Analysen (Frankfurt am Main, 1998), 208-9.

33. C. Wilson, The Occult (London, 1971), 441.

34. E. Münster-Schröer, 'Hexenverfolgungen in Jülich-Berg und der Einfluß Johann Weyers', Spee-Jahrbuch, 7 (2000), 59-102, especially 77.

35. Cf. F. Irsigler and A. Lasotta, Bettler und Gaukler, Dirnen und Henker. Randgruppen und Außenseiter in Köln 1300-1600 (Cologne, 1984), 152-3; F. W. Siebel, Die Hexenverfolgung in Köln (Bonn, 1959), 33-4.
36. Bodin, On the Demon-Mania (translated by Scott), 128 .

37. Summers, The Werewolf, 252, mentions a case at 'Dalheim' in 1581, but this should be Dalem in Lorraine; see Nicolas Rémy, La Démonolâtrie, translated by Jean Boës (Nancy, 1998), 210.

38. H. Keussen, 'Die drei Reisen des Utrechters Arnoldus Buchelius nach Deutschland, insbesondere sein Kölner Aufenthalt', Annalen des Historischen Vereins für den Niederrhein, 84 (1907), 1-102; 85 (1908), 43-114, especially 85 and 68 .

39. Quotes are from the reprint in Summers, The Werewolf, 253-6. The edition in Otten, Lycanthropy Reader, 69-76, is heavily edited.

40. C. Oates, 'Metamorphosis and Lycanthropy in Franche-Comté, 1521-1643', in M. Feher (ed.), Fragments for a History of the Human Body, I (New York, 1989) 304-63, especially 337.

41. Cf. Campangne, 'Arrest memorable', 356, where he cites De Lancre's wonder about werewolf names as Garnier and Grenier.

42. Irsigler and Lasotta, Bettler und Gaukler, 154.

43. Cf. P. M. Kreuter, 'Paracelsus - und der Werwolf?', Nova Acta Paracelsica, NF 20 (2007), 137-46.

44. L. Apps and A. Gow, Male Witches in Early Modern Europe (Manchester/New York, 2003), 135-6. This book suffers from a top-down view; cf. Schulte, Man as Witch, 4.

45. D. D. Gilmore, Manhood in the Making: Cultural Concepts of Masculinity (New Haven/London, 1990), 1.

46. L. Roper, 'Blood and Codpieces: Masculinity in the Early Modern German Town', in idem, Oedipus and the Devil: Witchcraft, Sexuality and Religion in Early Modern Europe (London/New York, 1994), 107-24.

47. Cf. M. Dinges, “" Hegemoniale Männlichkeit” - Ein Konzept auf dem Prüfstand', in: idem (ed.), Männer-Macht - Körper. Hegemoniale Männlichkeiten vom Mittelalter bis heute (Frankfurt am Main/New York, 2005), 7-33.

48. Cf. H. R. Schmidt, 'Hausväter vor Gericht. Der Patriarchialismus als zweischneidiges Schwert', in M. Dinges (ed.), Hausväter, Priester, Kastraten. Zur Konstruktion von Männlichkeit in Spätmittelalter und Früher Neuzeit (Göttingen, 1998), 213-36.

49. Cf. W. Schmale, Geschichte der Männlichkeit in Europa (1450-2000) (Vienna/ Cologne/Weimar, 2003). His concept of 'magic' is an extended one, with a main focus on extra-worldly communication; it is also very Catholic.

50. J. Jordan, 'Her-story Untold; The Absence of Women's Agency in Constructing Concepts of Early Modern Manhood', Cultural and Social History, 4 (2007), 575-83.

51. Keussen, 'Die drei Reisen', 52-3.

52. Cf. W. de Blécourt, "The making of the female witch: Reflections on witchcraft and gender in the early modern period', Gender \& History, 12 (2000), 287-309, especially 298-9.

53. S. van Leeuwen, Batavia Illustrata ofte Hollandsche Chronyk ('s-Gravenhage, 1685), 296-304; cf. Lea, Materials, 942.

54. Briggs, Witches of Lorraine, 365.

55. The assertion by Klaassen that it is possible to construct a character sketch of the sorcerer on the basis of the appearance of spelis to accomplish love magic or good detection and others (see Klaassen, 'Learning and Masculinity', 62) 
is wide of the mark. These spells were part of a sorcerer's professional 'toolkit', to be utilized for clients, not intrinsic elements of his character.

56. Especially when they were punished as cunning folk, which usually (according to the Carolina and other laws) meant banishment, they should not be confused with male witches, cf. A. Rowlands, Witchcraft Narratives in Germany: Rothenburg, 1561-1652 (Manchester/New York, 2003), 162-4. The capacity to discover stolen goods involved different techniques from those involved in treasure seeking.

57. For the seventeenth-century eastern Netherlands, see W. de Blécourt, Termen van toverij. De veranderende betekenis van toverij in Noordoost-Nederland tussen de 16de en de 20ste eeuw (Nijmegen, 1990), 111-3.

58. On Nassau, see J. Koppenhöfer, Die mitleidlose Gesellschaft. Studien zu Verdachtsgenese, Ausgrenzungsverhalten und Prozeßproblematik im frühneuzeitlichen Hexenprozeß in der alten Grafschaft Nassau unter Yohann VI. und der späteren Teilgrafschaft Nassau-Dillenburg (1559-1687) (Frankfurt, Berlin, etc., 1995); S. Richter, Werwölfe und Zaubertänze. Vorchristliche Glaubenvorstellungen in Hexenprozessen der frühen Neuzeit (Frankfurt, Berlin, etc., 2004). The interpretation in the latter book is insufficient, cf. W. de Blécourt, 'A Journey to Hell: Reconsidering the Livonian "Werewolf"', Magic, Ritual, and Witchcraft, 2 (2007), 49-67.

59. L. T. Maes, Vijf eeuwen stedelijk strafrecht. Bijdragen tot de rechts- en cultuurgeschiedenis der Nederlanden (Antwerpen/'s-Gravenhage, 1947), 208-9. I owe the information about the reception of the Stump pamphlet to Dries Vanysacker.

60. P.C. Molhuijsen, 'Bijdrage tot de geschiedenis der Heksenprocessen in Gelderland', Bijdragen voor vaderlandsche geschiedenis en oudheidkunde, NR 1 (1859), 194-209, especially $202-3$.

61. H. Aldieck, 'Akten und Urkunden zur Geschichte des Horster Gerichtswesens', Vestische Zeitschrift, 32 (1925), 180-206, especially 193-202. For another werewolf pole, see J. M. Eversen, 'Vonnis en executie wegens weerwolverij in 1607 door de justitie te Maastricht', De Maasgouw, 25 (1903), 95-6. Another one was erected in Horst in 1622.

62. B. Niehues, Zur Geschichte des Hexenglaubens und der Hexenprozesse vornehmlich im ehemaligen Fürstbisthum Münster (Münster, 1875), 83.

63. [Anonymous] 'Zauber und Gespenstergeschichten', Alemannia. Zeitschrift für Sprache, Literatur und Volkskunde des Elsasses und Oberrheins, 4 (1877), 161-81, especially 170 .

64. Otten, Lycanthropy Reader, 53; Wilson, The Occult, 440.

65. On Verjuz, see Schulte, Man as witch, 26; cf. B. Rowland, Animals with Human Faces. A Guide to Animal Symbolism (London, 1974), 165, who also discusses the medieval sexual symbolism of the werewolf.

66. C. Oates, 'The Trial of a Teenage Werewolf, Bordeaux, 1603', Criminal Justice History, 9 (1988), 1-29, especially 10.

67. M. Meurger, 'L'Homme-loup et son témoin. Construction d'une factualité lycanthropique', in J. de Nynauld, De la lycanthropie (Préaud \& JacquesChaquin (eds); Paris, 1990), 143-79, especially 170.

68. Cf. Münster-Schröer, 'Hexenverfolgung', 76-9.

69. See M. Zender, Sagen und Geschichten aus der Westeifel (3rd edn, Bonn, 1980), 372 (no. 1134); K. Bartsch, Sagen, Märchen und Gebrauche aus Mecklenburg (Vienna, 1879), 149; Hertz, Der Werwolf, 80.
70. A. Bruns, 'Die Oberkircher Hexenprotokolle', in A. Bruns (ed.), Hexen. Gerichtsbarkeit im kurkölnischen Sauerland (Schmallenberg, 1984), 11-90, especially $52,57$.

71. K. H. Spielmann, Die Hexenprozesse in Kurhessen (Marburg, 1932), 67-8.

72. E. Hoffman-Krayer, 'Luzerner Akten zum Hexen- und Zauberwesen', Schweizerisches Archiv für Volkskunde, 3 (1899), 22-40, 81-122, 189-224, 291-329, especially 90.

73. H.-P. Pracht, Täntze, Todt und Teuffel. Die grausame Spur der Hexenverfolgung in der Eifel (Aachen, 1991), 129-33; W. Dalhoff, 'Zu Rüthener Hexenprozessen', in A. Bruns (ed.), Hexen. Gerichtsbarkeit im kurkölnischen Sauerland (Schmallenberg, 1984), 177-88, especially 181-4; W. Niess, Hexenprozesse in der Grafschaft Büdingen (Büdingen, 1982), 284.

74. J. Rinscheid, 'Der Hexenwahn im Wildenburger Lande', Mitteilungen der Westdeutschen Gesellschaft für Familienkunde, 21 (1963), 203-76, especially 256; Spielmann, Kurhessen, 155.

75. K. Moeller, Dass Willkür über Recht ginge. Hexenverfolgung in Mecklenburg im 16. und 17. Jahrhundert (Bielefeld, 2007), 191-4.

76. Cf. the Maastricht werewolf of 1607 , who simply went by the name of 'le Loup' (see note 61).

77. Cf. I. Ahrendt-Schulte, Zauberinnen in der Stadt Horn (1554-1603). Magische Kultur und Hexenverfolgung in der Frühen Neuzeit (Frankfurt/New York, 1997) 213-35.

78. For the nineteenth- and twentieth-century werewolf back rider, see W. de Blécourt, " "I would have eaten you too": Werewolf legends in the Flemish, Dutch and German Area', Folklore, 118 (2007), 23-43.

79. Cf. Schmale, Geschichte der Männlichkeit, 48.

80. R. M. Karras, From Boys to Men: Formations of Masculinity in Late Medieval Europe (Philadelphia, 2003), 100-8. The connection between the figure of the beanus and the sabbat-presiding Devil in goat form needs to be further explored.

81. As in the particular werewolf legend, chopped-off hands also play in role in this story cycle, among others presented by Basile, Perrault, and later the Brothers Grimm; cf. J. Zipes, The Great Fairy Tale Tradition: From Straparola and Basile to the Brothers Grimm (New York/London, 2001), 26-50. 
Palgrave Historical Studies in Witchcraft and Magic

Series Editors: Jonathan Barry, Willem de Blécourt and Owen Davies Titles include:

Edward Bever

THE REALITIES OF WITCHCRAFT AND POPULAR MAGIC IN

EARLY MODERN EUROPE

Culture, Cognition and Everyday Life

Julian Goodare, Lauren Martin and Joyce Miller

WITCHCRAFT AND BELIEF IN EARLY MODERN SCOTLAND

Jonathan Roper (editor)

CHARMS, CHARMERS AND CHARMING

Alison Rowlands (editor)

WITCHCRAFT AND MASCULINITIES IN EARLY MODERN EUROPE

Rolf Schulte

MAN AS WITCH

Male Witches in Central Europe

Forthcoming:

Johannes Dillinger

MAGICAL TREASURE HUNTING IN EUROPE AND NORTH AMERICA

A History

Soili-Maria Olli

TALKING TO DEVILS AND ANGELS IN SCANDINAVIA, 1500-1800

Laura Stokes

THE DEMONS OF URBAN REFORM

The Rise of Witchcraft Prosecution, 1430-1530

Palgrave Historical Studies in Witchcraft and Magic

Series Standing Order ISBN 978-1403-99566-7 Hardback 978-1403-99567-4

Paperback

(outside North America only)

You can receive future titles in this series as they are published by placing a standing order. Please contact your bookseller or, in case of difficulty, write to us at the address below with your name and address, the title of the series and the ISBN quoted above.

Customer Services Department, Macmillan Distribution Ltd, Houndmills, Basingstoke, Hampshire RG21 6XS, England.

\section{Witchcraft and \\ Masculinities in Early \\ Modern Europe}

Edited by

\author{
Alison Rowlands \\ Senior Lecturer in European History, University of Essex
}

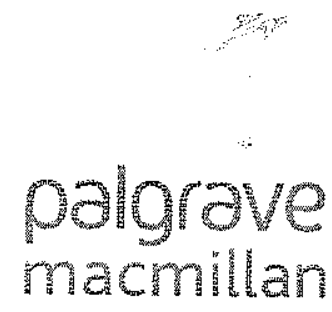

